\title{
Metacognitive Strategies Used by Students of Andalas University in Writing Paragraph
}

\author{
Jufrizal $^{1}$, Nelmira Dewita ${ }^{2 *}$ \\ ${ }^{1}$ English Department, FBS Universitas Negeri Padang, Padang, Sumatra Barat 25131, Indonesia \\ ${ }^{2}$ English Department, FBS Universitas Negeri Padang, Padang, Sumatra Barat 25131, Indonesia \\ *Corresponding author. Email: nelmiradewita@gmail.com
}

\begin{abstract}
Writing task is still a difficult and challenging task for students. In order to face this condition, students must have strategies. One of strategies is metacognitive strategies. These strategies can help students to do the writing task. There are four strategies in metacognitive strategies, namely; planning, monitoring, problemsolving, and evaluating. The purpose of this research was to explore what metacognitive strategies used by the students of Andalas University. The method of the research was a descriptive qualitative research. The participants were the students of industrial Engineering. It was class B that consisted of 45 students. The instruments used to collect the data were observation sheet, questionnaire, and interview. This research was done in two meetings. In each meeting, the researcher observed the students during writing activities. At the end of class, the researcher distributed the questionnaire sheet that answered by the students and interviewed them then. Based on the data analysed, it was found that the most students used metacognitive strategies in writing.
\end{abstract}

\section{Keywords: Metacognitive Strategies, Writing, Paragraph}

\section{INTRODUCTION}

Writing is one of the four language skills. It is an act to express and convey what one's feeling and thinking. It can be a sentence, a text, an idea, or knowledge that is written into a paper. As Hamp-Lyons states in Omalley (1996: 136) that writing is a personal act in which writers take ideas or prompts and transform them into self-initiated topics. This skill is really needed in all aspect of life, such as economics, science, and social. Due to this, this skill must be mastered especially by academic learners.

Writing is taught in every level of education. Teaching writing has long been a challenge, especially teaching English writing. This condition is still being experienced by teachers or lecturers. Even, there are many researches about it. As Maggie Sokolik says (in Nunan 2015: 78) that writing is between process and product. It means that writing involves steps that a writer goes through in order to create a piece of written work.

Dealing with the condition above, the process of the writing is an important thing. The process of writing can help teacher or lecturer to see whether students understand about the process. By understanding this process, it is hoped that it results in a very good product of writing. A good product may tell good process of writing.

Basically, Hedge (2000:302) mentions that there are some activities involved in writing process. They are setting of goals, generating ideas, organizing information, selecting appropriate language, making a draft, reading, reviewing, revising, and editing. It short, it can be concluded that writing process is a complex process.

Since writing process is a complex process, it is important to consider about the strategies used by the writer and activities characterize the writing. The strategies deal with how a piece of writing comes into being. The strategies may vary across a range of writing tasks. Then, the strategies used also show the activities happen in writing process. In other words, it can be said that strategies and activities impact on product resulted.

During writing process, students find many problems. One of them is finding ideas. It is also faced by the students at Industrial Engineering Department of Andalas University. Preliminary observation was done by researcher to find out the problems faced by students there. By interviewing some students, she knew that most students have problems in writing. It was about ideas. This condition sometimes makes them lose concentration and give up finishing a task.

Besides getting help from teacher to finish their task, the students themselves must find ways to solve problem their problem. They should realize about using writing strategies to make them motivated while writing. Strategies used do not only help them to reach a goal, but also improve their learning performance. So, they have to find their learning strategies and try to develop it.

There are some learning strategies can be used in learning. They are cognitive strategy, memory strategy, social affective strategy, and metacognitive strategy. 
Among those strategies, metacognitive strategy can be a strategy to improve learning process. It is learning strategy that makes students use their own knowledge or strategies to help them accomplish a task by planning, monitoring, problem-solving, and evaluating. In other word, we can say it is about a process of using some strategies to reach a goal. Students can use metacognitive strategy for all modalities such as reading, speaking, writing, and listening. It means that this strategy is useful for them to improve their learning. Metacognitive strategy can help student to think higher level. Because they can monitor their thinking process, it means that they will find the solution about the problems exist and develop their thinking. Furthermore, metacognitive can improve learning performance, through all process in metacognitive, they can think critically.

As Chamot (1999:11) mentions that the model of learning strategy is metacognitive strategies. This model of strategic learning organizes learning strategies in such a way that they become manageable and helpful to students and teachers. This model outlines the process effective learners use to work through any challenging tasks and describe ways to transfer strategy use to other subject areas, as well as to real-life situations. This model cannot only be applicable in writing, but also listening, speaking and reading.

For example in writing, Goctu (2017) conducted a research entitled "Metacognitive strategies in Academic Writing". He analyzed the metacognitive strategies as learner language strategy in writing. He found that the students used and aware the use of metacognitive strategy. Thus, he suggested these strategies to raise EFL writing instructors' awareness in teaching and in order to train students to become self-regulated learners.

According to Flavel (in Livingstone: 1997) metacogntion consists of metacognitive knowledge and metacognitive experiences or regulation. Metacognitive knowledge refers to knowledge and information. Knowledge and information are really used in writing. Then, metacognitive experiences or regulation involved metacognitive strategies. They are sequential processes that one uses to control cognitive activities, and to ensure that a cognitive goal has been met. These processes help to regulate and oversee the learning.

Based on researcher's personal experience, the researcher has given known about the metacognitive strategies for students which help them to do writing. Writing is one of compulsory subject in Industrial Engineering of Andalas University. In other words, writing is imperative, especially for engineering students. They are hoped to be able to write effectively. Then, to get an effective writing, the students must have strategies for doing it.

Consequently, the students must have knowledge about metacognitive strategy. Metacognitive strategies help students to plan what they will write. There are four strategies in metacognitive strategies. They are planning strategy, monitoring strategy, problem-solving strategy, and evaluating strategy. To plan a writing task, they can do some steps or activities which help them to plan it. For example, they have to set goal. They have to know the goal what they write. It means that they have to use planning strategy. Then, monitoring strategy can be used by them to writing. One strategy in monitoring strategy is taking notes. They can take some notes to monitor their writing. This will help them to monitor what they are writing. Then, problem solving strategy is helpful for them to overcome problems they face during writing. One strategy in problem solving is using resources. The students may use some resources to finish their problem in writing. The resources they use are like books, journals, dictionaries, and the internet. Last, evaluating strategy is the last strategy in metacognitive strategies. After the students do the task, they can evaluate their task before submitting or reporting. One strategy in evaluating strategy is checking goal. The students have to check again what the goal of their writing task is. They can go back some information about the task.

Due to metacognitive strategies, those strategies can be said that they are applied in writing process. In writing, they used strategies before, during, and after reading. In which, in metacognitive, there is planning phase which is like strategies before writing, monitoring and problem solving is like strategies during writing, and evaluation phase is like strategies after writing.

From the explanation above, it can be inferred that strategy is needed in writing, especially for engineering students to have an effective writing. Metacognitive strategies are helpful in writing to get the effective writing. So, this condition makes researcher research what are the metacognitive strategies used by the engineering students, especially in Industrial Engineering Department of Andalas University.

\section{METHOD}

This research was designed into process qualitative research. It was to seek what metacognitive strategies used by the students in writing paragraph. . The participants of this research were the students at semester two of Industrial engineering department of Andalas University. The class consisted of 45 students. Data were gotten by observation, questionnaire sheet, and interview. Questionnaire sheets were full of questions adopted from Chamot (1999). After collecting the students' questionnaire sheet, the data were tallied, and then the score was calculated. The percentage was calculated.It was used to see what metacognitive strategies used most. To get the reality, observation and interview were considered about the data.

\section{RESULTS AND DISCUSSION}

In writing paragraph, most students use most strategies in planning strategies. There are four strategies including planning strategy. Each strategy was used by the students. In writing paragraph, students have to plan what they are going to write. To plan it, the students always use planning strategy 1 . It is setting goal. Students must set their goal in order they know what they are going to write. Also, the students often direct their attention, predict and manage their self in writing. On the contrary, a few students tried 
to activate their background know ledge to plan writing. The percentage could be seen in table below:

Table 1. The frequency of planning strategies used

\begin{tabular}{|l|l|l|}
\hline Planning strategies & Percentage (\%) & Remarks \\
\hline $\begin{array}{l}\text { Planning strategy 1 } \\
\text { (set goals) }\end{array}$ & 95 & Always \\
\hline $\begin{array}{l}\text { Planning strategy2 } \\
\text { (directed attention) }\end{array}$ & 60 & Often \\
\hline $\begin{array}{l}\text { Planning strategy3 } \\
\text { (activate background } \\
\text { knowledge) }\end{array}$ & 10 & Often \\
\hline $\begin{array}{l}\text { Planning strategy 4 } \\
\text { (predict) }\end{array}$ & 70 & Sometimes \\
\hline $\begin{array}{l}\text { Planning strategy5 } \\
\text { (Organizational } \\
\text { planning) }\end{array}$ & 60 & Often \\
\hline $\begin{array}{l}\text { Planning strategy 6 } \\
\text { (self management) }\end{array}$ & 75 & \\
\hline
\end{tabular}

Next, after students planned what they were going to write, they have to monitor their writing. There are some strategies that they can use. Based on the data, students used most strategies including in planning strategy. Of course, this condition helped them in writing. Monitoring guide them to be successful in writing. It could be seen in the following graphic:

Table 2. The frequency of monitoring strategies used

\begin{tabular}{|c|c|c|}
\hline Monitoring strategies & $\begin{array}{l}\text { Percentage } \\
(\%)\end{array}$ & Remarks \\
\hline $\begin{array}{l}\text { Monitoring strategy } 1 \\
\text { (ask if it makes sense) }\end{array}$ & 100 & Always \\
\hline $\begin{array}{l}\text { Monitoring strategy } 2 \\
\text { (Selectively attend) }\end{array}$ & 80 & Always \\
\hline $\begin{array}{l}\text { Monitoring strategy } 3 \\
\text { (Deduction ) }\end{array}$ & 65 & Sometimes \\
\hline $\begin{array}{l}\text { Monitoring strategy } 4 \\
\text { (personalize/ } \\
\text { contextualize) }\end{array}$ & 85 & Always \\
\hline $\begin{array}{l}\text { Monitoring strategy } 5 \\
\text { (take notes) }\end{array}$ & 85 & Always \\
\hline $\begin{array}{l}\text { Monitoring strategy } 6 \\
\text { (use imagery) }\end{array}$ & 85 & Always \\
\hline $\begin{array}{l}\text { Monitoring strategy } 7 \\
\text { (manipulate act out) }\end{array}$ & 95 & Always \\
\hline $\begin{array}{l}\text { Monitoring strategy } 8 \\
\text { (talk yourself through it } \\
\text { (self-talk) }\end{array}$ & 80 & Always \\
\hline $\begin{array}{l}\text { Monitoring strategy } 9 \\
\text { (cooperate) }\end{array}$ & 70 & Often \\
\hline
\end{tabular}

Then, the next strategies used were problem solving strategies. There are four strategies included. In writing paragraph, some difficulties might be found even though the students had done monitoring. The difficulties can be solved by the students themselves. They did inference, substitute, ask question, and use resources. Among the four strategies, students always ask question and use resources. They asked question to friend or teacher. Then, they used resources like dictionary, internet access, note, book, and magazines. The following table would show the percentage:

Table 3. The frequency of problem solving strategies used

\begin{tabular}{|l|l|l|}
\hline Problem solving strategies & $\begin{array}{l}\text { Percentage } \\
(\%)\end{array}$ & Remarks \\
\hline $\begin{array}{l}\text { Problem solving strategy 1 } \\
\text { (inference) }\end{array}$ & 60 & Often \\
\hline $\begin{array}{l}\text { Problem solving strategy } 2 \\
\text { (substitute) }\end{array}$ & 75 & Often \\
\hline $\begin{array}{l}\text { Problem solving strategy } 3 \\
\text { (ask question to clarify) }\end{array}$ & 85 & Always \\
\hline $\begin{array}{c}\text { Problem solving strategy } 4 \\
\text { (use resource) }\end{array}$ & 80 & Always \\
\hline
\end{tabular}

The last strategies used by students in writing paragraph were evaluating. These strategies were used in the writing activity where the students tried to evaluate their writing before they submitted the task. In evaluating strategies, they did not only evaluate their task, but also their strategy. In evaluating, they students always predicted about the task and guessed whether their task had met completely. The table below would give the percentage of the evaluating strategies used:

Table 4. The frequency of evaluating strategies used

\begin{tabular}{|l|l|l|}
\hline Evaluating strategies & $\begin{array}{l}\text { Percentage } \\
(\%)\end{array}$ & Remarks \\
\hline $\begin{array}{l}\text { Evaluating strategy 1 } \\
\text { (verify prediction and } \\
\text { guesses) }\end{array}$ & 90 & Always \\
\hline $\begin{array}{l}\text { Evaluating strategy 2 } \\
\text { (Summarize) }\end{array}$ & 85 & Olways \\
\hline $\begin{array}{l}\text { Evaluating strategy 3 } \\
\text { (check goals) }\end{array}$ & 75 & Often \\
\hline $\begin{array}{l}\text { Evaluating strategy 4 } \\
\text { (evaluate yourself) }\end{array}$ & 70 & Always \\
\hline $\begin{array}{l}\text { Evaluating strategy 5 } \\
\text { (evaluate your strategy) }\end{array}$ & 90 & Often \\
\hline $\begin{array}{l}\text { Evaluating strategy 1 } \\
\text { (verify prediction and } \\
\text { guesses) }\end{array}$ & 75 & \\
\hline
\end{tabular}

The four tables above showed that most metacognitive strategies are used by the students and most students used those strategies, too. It can be said that metacognitive strategies are significantly used in writing paragraph.

\section{CONCLUSION}

Most students use metacognitive strategies in writing paragraph and most strategies are used by them. The strategies are really helpful for them in writing paragraph. This research can give contribution theoretically and practically. Theoretically, it gives contribution to language learners' strategies in writing. These strategies lead the students write effectively. It can be emphasized that 
metacognitive strategies can be expanded to increase students' English writing ability. Practically, it gives contribution to teachers who teach writing. Teachers can lead the students to use these strategies in writing. It is really meaningful to make students do good writing, especially writing paragraph.

\section{ACKNOWLEDGMENT}

First and foremost, the researcher would like to say Alhamdulillah all praise to Allah SWT for giving me strength and encouragement during all the moments in completing this research. Then, the researcher gives a massive thank to Mr. Jufrizal as the advisor. The researcher greatly appreciates all his enormous contributions of time and ideas, as well as his support of the researcher's interest in the current topic of the research. It was an honour to have such a knowledgeable advisor who challenged and encouraged to do the best throughout the whole time spent on writing the research. Without his guidance and persistent help, it would not have been possible. The researcher would also like to show the gratitude to Mrs. Yetti Zainil and Mr. Muhd Al-Hafizh, as well as many other amazing university lecturers. The researcher has greatly benefited from their lectures, which will always remember as the best time of life.

\section{REFERENCES}

[1] Brown, H. Douglas. 2001. Teaching by Principles: An Interactive Approach to Language Pedagogy, Second Edition. New York: Pearson Education Inc.

[2] Brown, H. Douglas. 2004. Language Assessment: Principles and Classroom Practices. New York: Pearson Education Inc.

[3] Chamot, Anna Uhl (et al.). 1999. The Learning Strategies Handbook. New York: Longman.

[4] Gay and Airasian Peter. 2000. Educational Research: Competencies for Analysis and Application. (Sixth Edition). Tokyo: Prentice Hall,Inc.

[5] Goctu, Ramazan. 2017. Metacognitive in academic writing. Journal of Education in Black Sea Region vol 2.issue 2, $2017 \quad$ (online) (https://www.researchgate.net/...317717123)

[6] Hedge, Tricia. 2000. Teaching and Learning in the Language Classroom. Oxford University Press.

[7] Linse, C. T (Ed). 2005. Practical English Language Teaching: Young Learners. New York: McGraw-Hill Inc.

[8] Nunan, D. 2003. Practical English Language Teaching. New York: Mc Graw Hill Companies.

[9] Nunan, D. 2015. Teaching English to Speakers of Other Languages: An Introduction. New York: Routledge.

[10] O'malley, J. Michael and Lorraine Valdez Pierce. 1996. Authentic Assessment for English Language Laerners: Practical Approaches for teachers.
United States of America: Addison-Wesley Publishing Company.

[11] Sugiyono. 2012. Memahami Penelitian Kualitatif. Bandung: Penerbit Alfabeta.

[12] Scott, Wendy A and Lisbeth H. Ytreberg. 2001. Teaching English to Children. New York: Longman. 